\title{
Extreme Cities and Isotropic Territories: Scenarios and Projects Arising from the Environmental Emergency of the Central Veneto Città Diffusa
}

\author{
Lorenzo Fabian* \\ Department of Urbanism, University IUAV of Venice (Istituto Universitario di Architettura di Venezia), 30125 Venice, Italy
}

\begin{abstract}
In Italy extreme cities and territories occur at the extremities of lagoons, coastlines, and river deltas, in hydraulically reclaimed and hydrogeologically instable areas, and those where the water supply network has been placed underground, channeled into piping, or removed altogether. These areas are now increasingly subject to natural calamities and extreme weather conditions, and the consequences of climate change and the fragility of the more and more impermeable and urbanized land surface are clearly evident. Isotropic territories are characterized by weak hierarchization of infrastructure and settlement. The metropolitan area of Venice, aptly described as a diffuse city (città diffusa), and other diffusely organized territories characterized by settlement dispersion are good examples of this phenomenon. This article reviews recent research at the University IUAV of Venice in a study on climate change and water forms, a project in which the profound relations between water networks, the geological nature of the terrain, forms of urbanization, and energy saving are tested out. The study of the territories of the Venetian metropolitan area provides a series of initial working hypotheses as to how the ongoing environmental emergency can become an opportunity for a development project of the city and the territory, capable of structuring its various parts differently.
\end{abstract}

Keywords città diffusa, climate change, energy project, Veneto, water management

\section{Introduction}

Starting from the disastrous effects of intense meteorological events that over the years have struck the Italian territory in general and the territory of the central area of the Veneto region in particular, this article introduces some of the main themes of the projects that urban planning will have to undertake to tackle the environmental and hydrogeological risks that derive from the climate change underway.

In the following the issue of hydrological risk on Italian territory and the relations in the Mediterranean regions

\footnotetext{
* E-mail: Ifabian@iuav.it
}

between climate change and the increase in the frequency of extreme meteorological events are introduced. The study illustrates how the condition of hydrogeological risk, that until recently only affected specific locations, today is a concern in much of Italy. The environmental, climate change, and hydrogeological risk questions of the central Veneto città diffusa ("diffuse city" in Italian) can lead to new and important territorial project themes, to the revision of some of the fundamental concepts of urbanism, and also introduce a potential revision of the epistemological status of its development projects and priorities.

Subsequently, the theme of the extreme city is discussed based on the specific case study of the central area of the Veneto region by researchers of the University IUAV of Venice. The territory of the Veneto is taken as a paradigm of a territorial condition of settlement dispersion in which water and agricultural and urbanized spaces are closely related. The relations between hydrogeological risk, soil surface sealing, the development project of the territory, and its infrastructure are illustrated.

Based on the research work and the project experimentation carried out in the Veneto region, some possible strategies for adaptation to climate change and the mitigation of the hydrogeological risk through the possible regeneration of water landscapes are illustrated. The objective of the highlighted project experiments is the possible creation of infrastructure capable of providing effective responses to the hydrogeological problems, promoting an increase in biodiversity, and satisfying the demand for spaces for leisure activities, sports, and social contacts.

Finally, the relations between environmental regeneration, the territorial development projects, and the energy network are analyzed. The case of the Veneto and strategies aimed at mitigating $\mathrm{CO}_{2}$ emissions show how a spatial correlation should exist between territorial and energy models, and how a different and more effective mode of producing energy might also influence land use and the organization of urbanization, the density of settlements, and the mobility infrastructure. 


\section{The Extreme and the Ordinary}

In 2010 the European Climate Foundation carried out the study Roadmap 2050: A Practical Guide to a Prosperous, Low-Carbon Europe (ECF 2010). The study, organized in five volumes and promoted by the European Commission, is an analysis of the ways in which, by 2050 , a low-carbon economy might be organized in Europe. In the third volume of the study, Graphic Narrative, a graph overlaps the progression of the series of global natural disasters with the global rise in temperatures in the period from 1950 to 2010. In showing that the two phenomena are growing in tandem in terms of rhythm and acceleration, the graph (OMA 2010, 16) shows the relation between climate change and natural events with catastrophic consequences. The increasing evidence of the consequences of intense meteorological events that have hit Italy over recent years has also made the possible consequences of climate change manifest. These facts and events have highlighted how conditions that we could have until recently considered exceptional or extreme are becoming more frequent, widespread, and ordinary in our contemporary territory.

Between 30 October and 2 November 2010, after several days of intense rain (500 $\mathrm{mm}$ in 48 hours) (Barbi et al. 2007), the rivers Bacchiglione, Timorchio, Retrone, Alpone, Tramignia, and Frassine overflowed, producing a flood that hit the heart of the "diffuse city" of the Veneto region, a portion of the territory featuring a dispersion of houses, schools, factories, and infrastructure. The report by the Veneto Regional Council (Structure of the Extraordinary Commission for
Recovering from the Flooding 2011) illustrates the extent of the damage: some 130 municipalities were affected, 500,000 persons suffered damage to their homes or workplaces, and 30 percent of the provincial territory of Vicenza was entirely covered by water. The water and mud invaded roads, piazzas, factories, basement garages, housing, businesses, stables, livestock farms, and cultivated fields (Figure 1).

Just a few weeks before, in Milan, in an area not new to this type of event, the rain and bad weather had caused the flooding of the north of the city and the consequent overflow of the river Seveso, that over the years has been almost totally covered over and tunneled underground under the pressure of the progressive soil surface sealing that prevails in the northern area of the province of Milan (ONCS 2009; ERSAF 2010). In February 2010, in the municipality of Maierato in the province of Vibo Valentia, southern Italy, due to sudden and violent cloudbursts nearly two million cubic meters of clayey material slid away, corresponding to the entire hillside skirting the hamlets of Draga, Mosto, and Giardino. A tragedy was only avoided thanks to the preventive evacuation of the 2300 inhabitants of the town (Comerci and Di Manna 2010). Between October 2009 and February 2010, several towns in the province of Messina (Sicily) were affected by hydrogeological disturbances. As illustrated in the report by Legambiente (League for the Environment) with the Civil Defense Department as part of the river-flood risk report Operazione Fiumi 2010, since October 2009 eight Italian regions - from Liguria to Tuscany, the Veneto and the triVeneto, Calabria to Campania, and Sicily to Emilia Romagna - have been struck by hydrogeological emergencies, leaving

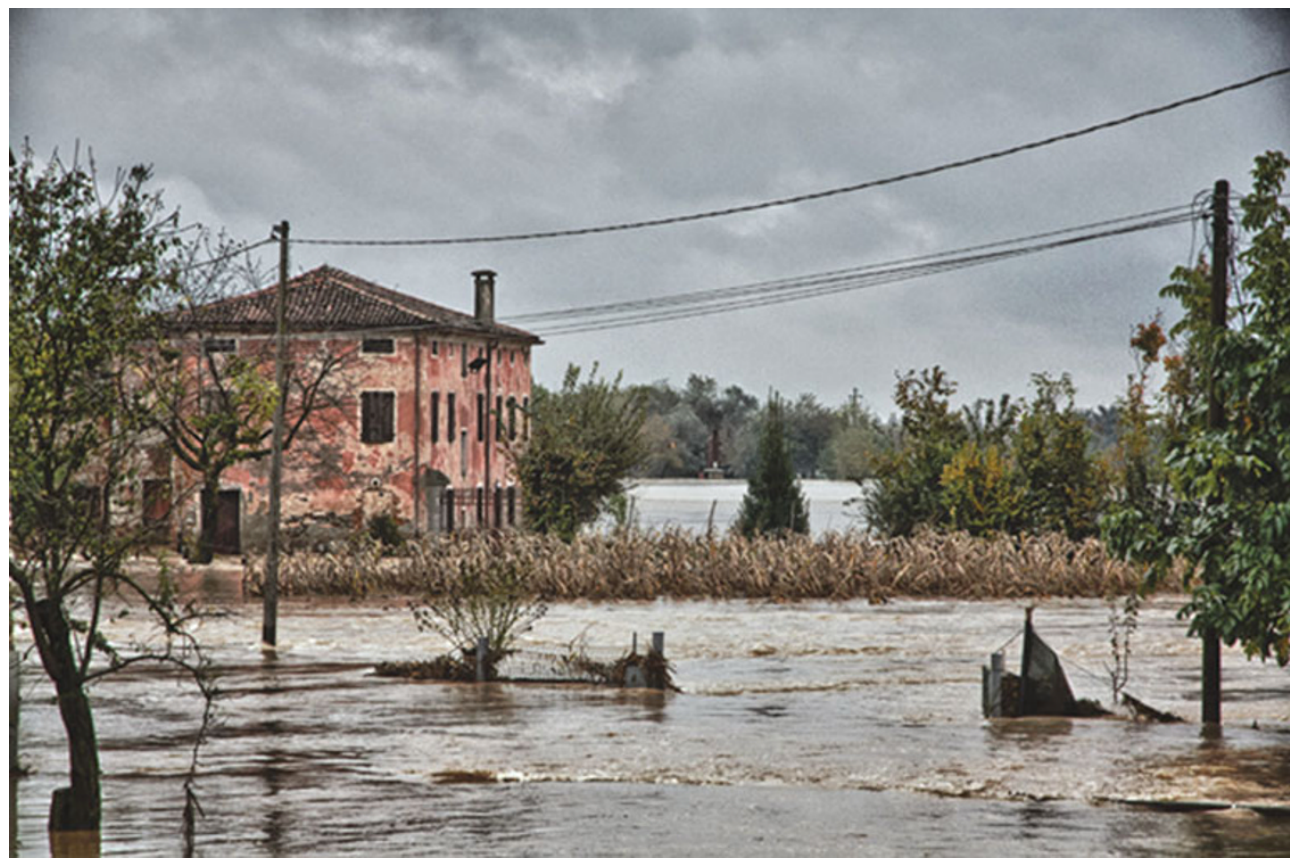

Figure 1. Casa del Castello di S. Martino della Vaneza during the flooding of the Bacchiglione River in the Veneto region Photograph by G. Cordellina, 2 November 2009.

Reprinted with Permission from G. Cordellina. 
a death toll of 52 and damage of at least 650 million Euros. An estimated 6633 Italian municipalities have areas classified as being at high hydrogeological risk, accounting for 82 percent of all Italian municipal authorities (Legambiente, Civil Defense Department 2010).

Recent research on extreme meteorological phenomena that have occurred in the Veneto region (Gissi 2010) shows that the pluviometric values of the rainfall affecting the region in the last 50 years indicate the potential extent of the transformations that can be attributed to climate change. A study by Bixio (2009) that deals with meteorological events that have affected the Veneto highlights how, starting from the 1980 s, the occurrence of extreme rainfall has progressively increased in rhythm and intensity. From the 1980s to 2007, according to Bixio, this progression led to the progressive halving of the estimated time of recurrence of these extreme events. As Gissi observes, these circumstances are perfectly in line with the forecasts of the Intergovernmental Panel on Climate Change (IPCC) who assumed that climate change in the Mediterranean regions would occur as a progressive increase in intense meteorological phenomena interspersed by long periods of drought (IPCC 2007). The relations between global warming and the increase in the probability of the occurrence of violent meteorological phenomena are also highlighted in a study by Conte, Sorani, and Piervitali (2002) on extreme climatic events over the Mediterranean. This study speaks of a "meteorological bomb" in identifying extreme rainfall with characteristics very similar to the rainfall events previously described.

But the damage caused by these events does not depend exclusively on the growing intensity of meteorological phenomena. It also depends on a progressive and radical process of soil surface sealing through the increase in infrastructure, built-up areas, and overall urbanization that the Italian territory has been broadly subjected to since at least the 1960s (Pileri 2010). It is not by chance, as highlighted by the 2010 report on land use promoted by National Observatory of Land Use, that many territories hit by disastrous events are situated in the most populated regions with the greatest soil surface sealing rates in Italy (ONCS 2009).

The increased occurrence of extreme meteorological events and the damage caused by them reveal the deep relations between climate change, extreme catastrophic events, and urbanization, and indicate that the extreme cities are and will increasingly coincide with ordinary territories, where many Italian citizens live and work.

The terms "extreme" and "ordinary" serve to illustrate this paradox: more and more often throughout the Italian territory, ordinary places, that were not considered subject to particular conditions of risk, have in but a few hours become the theater of devastation caused by extreme meteorological conditions. From this point of view the extreme city is not only an image useful in describing particular places and situations. It is also useful for describing the potential risks that many ordinary parts of Italian territory are subject to. At the same time if "trains are only seen to exist when they derail" (Perec 1996,
11), the extreme meteorological events that in these last years have hit Italy and the Veneto region also throw light on the distinguishing traits (all too often neglected) of the Veneto as an ordinary territory, on its specific nature and fragility; a territory that is the result of processes that lasted for thousands of years where water, agricultural, and urban spaces are profoundly and closely interrelated.

\section{Extreme City and Dispersed City}

Some recent learning and research activities carried out by the University IUAV of Venice have tackled these themes ${ }^{\mathrm{i}}$ based on the specific case of the "diffuse city" of the Veneto region, an area of some $50 \mathrm{~km} \times 50 \mathrm{~km}$, including from west to east the area between the rivers Brenta and Piave, and from north to south the area running from the fringe of the alpine foothills to the Venetian Lagoon. The case study, at the same time paradigmatic and specific, enables reflection on some of the paradoxes and contradictions typical of the contemporary city and contemporary territory.

The territory that is the object of the study, the central area of the Veneto region, is paradigmatic because it is literally constructed by water. Everything - from the organization of the cultivated fields, to the minute infrastructural capillary networks, to the distribution of the settlements - tells of a process of long periods of different strategies of intervention, the purpose of which has been distributing water where it is lacking and eliminating water where it occurs in excess.

The complex and composite legacy of infrastructural elements and other items built by man that characterize the topography of this region is the result of a thousand-year process of construction of the territory, the process of control and governing of water and its infrastructure (Viganò 2010). The central area of the Veneto is the result of an integral construction of the territory starting from the Roman aggeratio ${ }^{\text {ii }}$ (Pesavento 1998), going on to the great works of canalization of the Venetian Republic, and continuing with processes of land reclamation carried out at the beginning of the twentieth century (Bevilacqua and Rossi-Doria 1984; Bevilaqua 1989).

Bridges, locks, dikes, embankments, canals, channels, drainage ditches, rectifications, and deviations are only some of the constituent elements of the different strategies and approaches that during the course of history have given shape to the territory of the città diffusa. Recognizing and describing the different strategies that have been inscribed and will be inscribed on the territory means understanding and decoding the design that is implicit in the area in question (Dematteis 1995). It means observing the evolutionary horizons in relation to the growing demand for public spaces and environmental quality and to the needs derived from the risks that will increasingly feature in the water spaces of the future.

The central area of the Veneto is often taken, in Italy as well as in Europe, as an emblematic case of a dispersed urban 
condition with a weak hierarchy, featuring the pervasive diffusion of objects, assets, and facilities and progressive soil surface sealing that is the consequence of urban development (Munarin and Tosi 2000; De Geyter 2002). To describe this particular urban condition that cannot be captured by the conceptual categories of modern urbanism, the term città diffusa (Indovina 1990) is often proposed.

The diffuse city of the Veneto is in fact an extreme city because it is one of the most impermeable but also one of the rainiest and water rich regions of Italy. It is located at the extremity between land and water (Figure 2) and over the last few years the area has registered an acceleration in sudden and violent rainfall.

This is a part of Italy that features an enormous, capillary, and highly evident system of technical devices, deriving from the infrastructure for channeling and controlling water. At the same time there is a dearth of water resources and their quality is often poor (Bixio 2009; Gissi 2010). This paradox features in many other contexts throughout Italy and is strictly correlated to the serious consequences of climate change, progressive urbanization resulting in soil surface sealing, and evolutions in lifestyle. The climate change in the area is acquainting us with long periods of drought, interspersed with sudden and violent cloudbursts; the widespread soil surface sealing creates ground with a poor capacity to absorb/ dissipate water in excess while increases runoff, and makes for an increasingly fragile and vulnerable territory. The progressive soil surface sealing is generally the prime reason for the non-dispersal of rainwater in the event of sudden and intense downpours. Less infiltration also means less recharging of the water tables, reduced capacity of the territory to hold rainwater, and greater hydrogeological risk in the event of extreme rainfalls.

The flooding that hit the region on 2 November 2009 highlights how the costs of this situation are becoming heavier and more unbearable, and this not only from an environmental point of view. If it is in fact true, as the regional governor Luca Zaia declared, that in this dramatic circumstance the

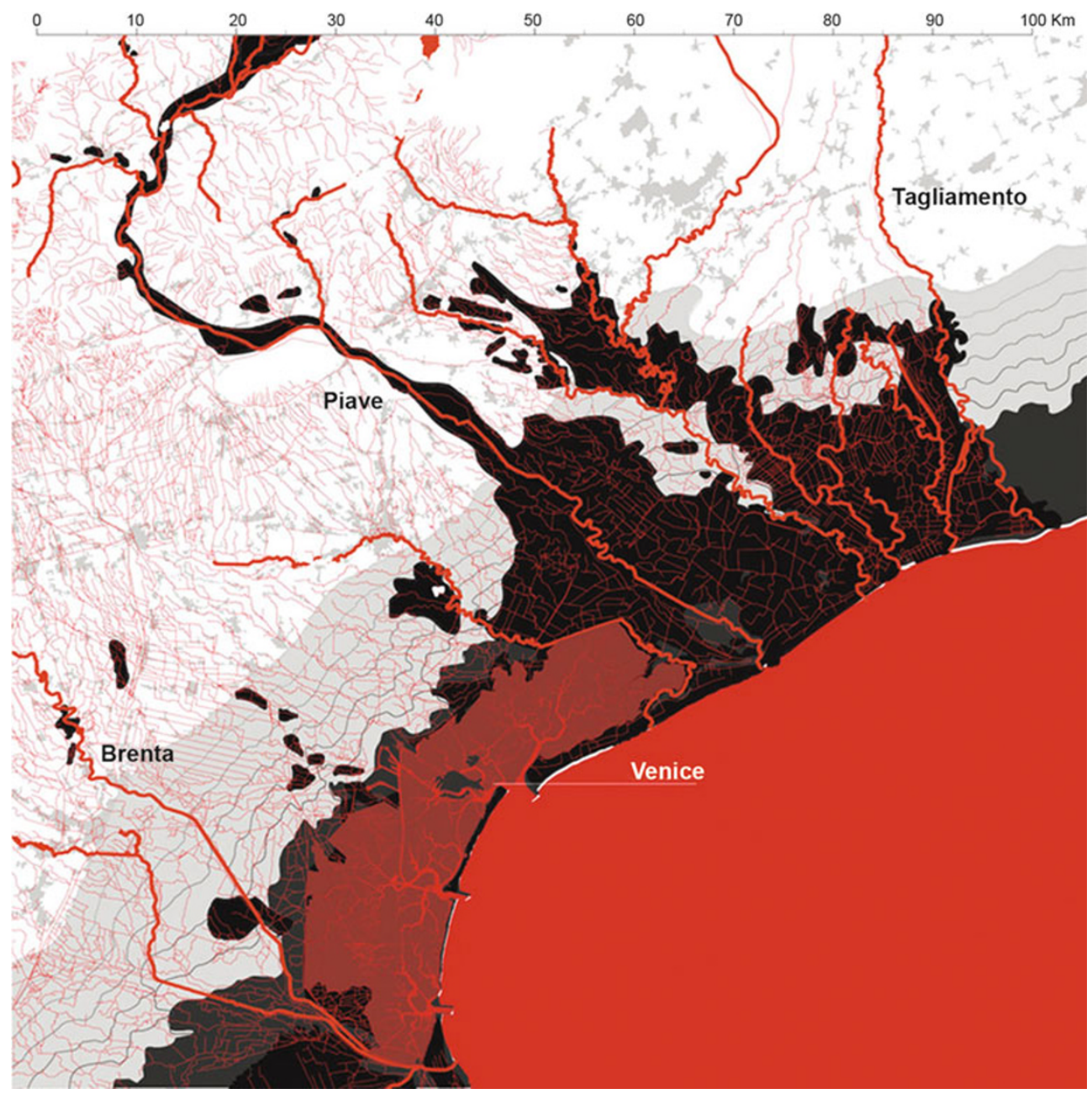

Figure 2. The extreme city of the Veneto region

Red: water; black: floodplain; gray: urbanized areas; light gray: 5-m contour line.

Source of data: Regional Territorial Coordination Plan (Department of Land Policies, Veneto Region 2009); Water Protection Plan (ARPAV 2006); Corine Land Cover 2000 Seamless Vector Database (EEA 2007); and DTM 2004 (EEA 2004). 
Veneto region was left by the Italian government to fend for itself, it is also true that what happened is, at least partially, due to decades of policies of territorial administration that have all too often favored land consumption over questions of the environmental and hydrogeological safeguarding of the territory. The widespread urbanization, for example, has increased the probability that events of this nature occur and the presence of assets and people in areas where these events are liable to happen. In the province of Venice, in 2010 alone, $1.5 \mathrm{~km}^{2}$ of land surface was sealed (Zanchini 2010). Water spaces are becoming further compressed and vulnerable and flooding is becoming more frequent. To this should be added the paradox of a physiological dearth of water due to the fact that enormous quantities of drinking water are wasted because of a continuously growing domestic demand and deficiencies in obsolete irrigation systems (Petrella 2002).

\section{Landscape of Water}

To address the issues identified above and their possible implications for the planning of the territory we involved dozens of students of the European Masters in Urbanism (EMU), the Masters Degree Program in Architecture, and the Graduate Program in Urbanism at the Faculty of Architecture of University IUAV of Venice.iii Over the past years we have developed and tested scenarios, working hypotheses, and project experimentations. The projects and studies developed in these contexts have enabled reflection on the modality by which, starting from a specific territory, environmental emergencies and hydrogeological risk can become opportunities for a renewed plan of the city and the territory, capable of differently structuring its parts. Designing the space of water, of hydrological risk, and the devices for reducing energy consumption and producing renewable energy, means, also and above all from a spatial point of view, reconceptualizing the future development of the city and the territory. The research and project experimentations illustrated below have enabled the measurement of the spatial and other consequences and the relative opportunities for the diffuse city of the Veneto in applying some alternative strategies of mitigation or adaptation, in the hope of dealing with the main hydraulic problems deriving from the climate change underway.

\subsection{More Space for Water}

With the approach of "more space for water" some project strategies explore the possibilities of organizing places for planned flooding around the extended areas of riverbeds in some portions of agricultural or urban green spaces. This approach exemplifies hydraulic risk control strategies already adopted in the Netherlands that are based on the organization of resilient spaces or wetlands capable of absorbing water in the event of flooding.

Starting from this strategy some projects drawn up at the IUAV for the Veneto area explored the possible creation of a large resilient regional infrastructure, built along the riverbeds, the coastline, and the lagoon, around the disused quarries, and the high-speed infrastructure for the mobility of the diffuse city of the Veneto. The goal is to give greater space to water through drainage water flow and water storage, as well as by increasing natural infiltration through processes of afforestation, the reconstruction of wetlands, and the recovery and increase of areas of spontaneous vegetation (Fabian, Secchi, and Viganò 2012).

The expression ruimte voor rivier, literally "room for the river," is a Dutch phrase that summarizes the fundamental principles of this strategy and the Dutch flood defense policies. The water policy of the Netherlands (NBEPA 2005) conforms to the Water Framework Directive 2000/60/EC (EU 2000) and recognizes that in future years, in the light of climate change and the processes of global warming, the rise in river water levels and the acceleration in the rising of sea levels will render insufficient many resistant type of technical measures of classic hydraulic engineering such as the building of dikes or dams or other mechanical barriers. Thus, the ruimte voor rivier strategy promotes hydraulic and urban planning actions aimed at restoring more space to water, including the elimination of resistant barriers in favor of an organization of resilient spaces and devices (Hulsker et al. 2011).

The concepts of resistance and resilience began to gain hold in ecology in the 1970s, indicating the two major ways through which a system can handle a potentially destructive change (Holling 1973). Resistance is expressed in the capacity of a system to stand up to change. Resilience indicates the capacity of a system to deform as a consequence of external pressure and to then return to its original state once the conditions permit.

Applied to hydraulic engineering and the problems of flooding, resistance is represented by dikes, dams, and all those devices that in a rigid manner stand up to hydraulic risk; resilience is reflected in the drainage basin, wetlands, and all those measures that by giving more space to water prepare for programmed flooding but return to their original state when environmental conditions allow.

Within a strategy of adaptation to climate change that integrates hydraulic policies with cultural and territorial policies in the broadest sense, the IUAV student projects explore resilient types of actions and devices. These are aimed at restoring and safeguarding the extended areas of the river basins that lead to the lagoon-in some cases eliminating dams and returning whole chunks of reclaimed territory to the water-while preserving the historical and cultural value of the Veneto river landscapes wedged as they are within the diffuse city. Some of the student projects explore the extension of the lagoon surface southwards into the low-lying areas of reclaimed land to contribute to an elastic and resilient organization of the territory, an amphibious territory dotted by areas with consolidated urban nuclei protected by banks. These scenarios reconstruct conditions similar to those 
that featured in the low wetland plains prior to the land reclamation carried out during the Fascist era.

To the north of the above area, to give water more space, the experimentation envisaged the creation of a new territorial park around the disused quarries located in the northern territories of the dry upland plain in the central area of the Veneto region. Through a principle already tested in some pilot projects (Viganò et al. 2009), the abandoned quarries are connected to the river system and converted into retention ponds for water drainage in the event of flooding, storing excess water for irrigation purposes in periods of drought.

Within this logic, the plan that has traditionally given substance to the design of the city and territory (Secchi 1986) assumes a new dimension: through the control of the microtopography of the ground we can govern hydraulic problems and construct a new landscape for the diffuse city of the Veneto (Figure 3). The riverbeds, the abandoned quarries, the edges of the lagoon, and the city parks in these projects take on many functions: resilient infrastructure for programmed flooding and water storage, ecological corridors for biodiversity, public spaces for sports and leisure activities, and the redesigning of the città diffusa.

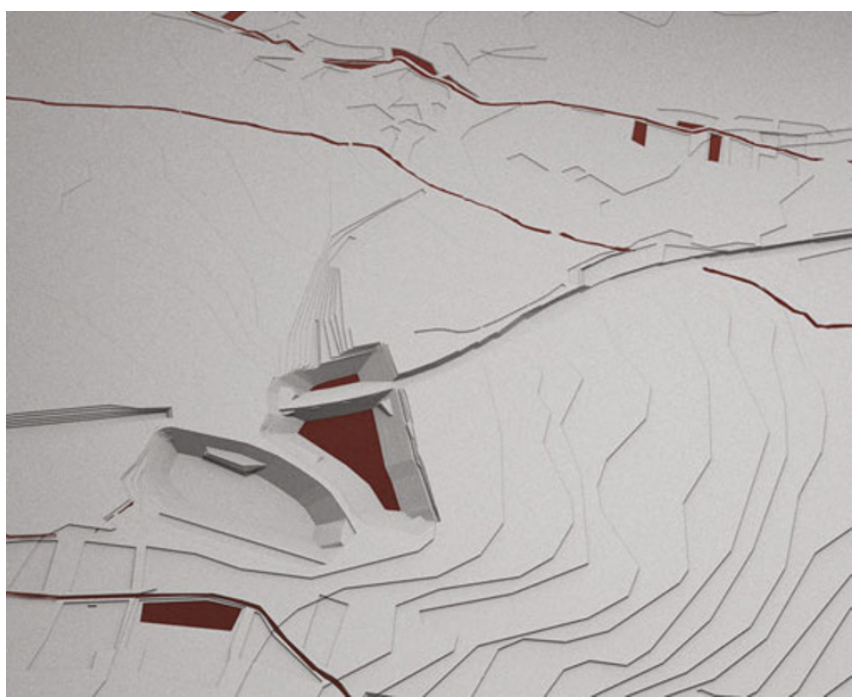

Figure 3. A resilient regional infrastructure built along the riverbeds and around the disused quarries of the Veneto region

Source: Exploratory project by C. Pisano, C. Roch Saiz, and V. Saddi, EMU (European Postgraduate Master in Urbanism), University IUAV of Venice. Coordinated by B. Secchi and P. Viganò, Fall semester 2010 (exploratory project model).

\subsection{Every Drop Counts}

With the "every drop counts" approach some project strategies aim at a more efficient use of water resources. The expression is from the title of a publication of Delft University of Technology on the theme of hydrological efficiency (Schuetze and Tjallingii 2008). It implies the need of a systematic approach to solving water problems that cuts across the entire water cycle at different scales and creates a progressively expanding set of good practices and projects.
In relation to this approach, the policies under discussion to contain the environmental problems deriving from global warming converge on one point: general solutions to the problem do not exist (neither on a global, nor on a local scale) that can be exclusively applied to the organization of largescale resilient territorial infrastructure. The solutions to environmental problems, the supply of water resources, and the protection from flooding need to include policies aiming at the mobilization of individuals, a radical change of lifestyle and habits, and an increasing awareness that every drop counts in the pursuance of water efficiency. "Our models of thought, behavior, production and consumption are suited to the current circumstances, or that is to the current climate, the twentieth century abundance of cheap energy and water [...]" (McNeill 2000, XIII). Starting from the awareness that conditions have changed, that water is a resource (also an economic resource) and a collective asset, we examined the possibility of a radical reduction of water consumption in the domestic environment. This implies individual mobilization, the consequences and success of which can be measured on a territorial scale. Some project explorations imagined the creation of a series of networked capillary domestic devices with the objective of incrementally increasing water efficiency. These devices include the collection and storing of rainwater at the foot of dwellings to satisfy demand also in periods of drought; the creation of wadis, small depressions in the ground attached to the dwellings to absorb the impact of violent rainfall; and small phytopurification systems for the reuse of gray water for irrigation and domestic nondrinking purposes (Zaccariotto 2010) (Figure 4). As part of this strategy, some processes of incremental regeneration of agricultural spaces are favored: the recovery and maintenance of ditches; plants bordering allotments and the edges of fields to capture rainwater and maintain soil moisture; and water purification by creating woodland buffer areas set up to act as filtering devices. The subject of water efficiency requires that both the architectural and urban plans contribute to this process of incremental change of the constituent items that make up the ordinary territory of the diffuse city of the Veneto.

\section{Landscape of Energy}

Whether the hydrogeological risk management projects are the result of a resilient or resistant approach, they are essentially adaptive projects. Actions intended to reduce climate change have to necessarily go towards mitigating emissions and the planning of a territory with low carbon usage. To tackle climate change the European Union has recently approved an integrated energy strategy that sets ambitious objectives for 2020 and 2050 and goes well beyond the limits laid down by the Kyoto protocol. ${ }^{\text {iv }}$ Current policies, the climate change debate, and the recent planning experiences and constructions of visions for great metropolitan areas (The Greater Paris (Ministry of Culture and Communication of the French Republic 2009); EU Roadmap 2050 (ECF 2010)) 

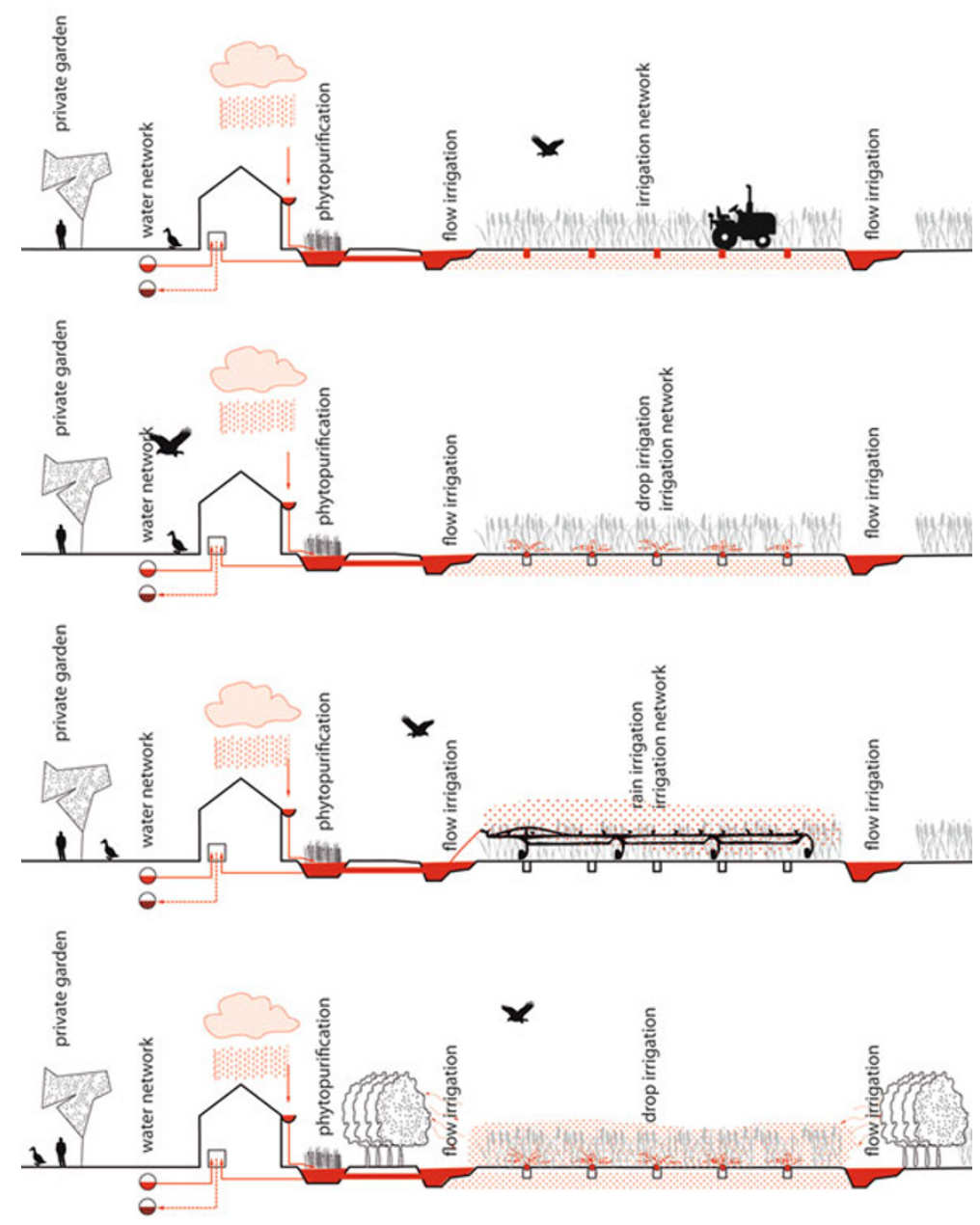

Figure 4. Domestic devices for water efficiency in the Veneto region

highlight how the successful attainment of emission reduction goals will also have an important impact on architectural and urban planning. It would imply a deep revision and restructuring of existing properties, of density and patterns of urban settlements; an overhauling of the systems of mobility and accessibility; and a redefinition of the relations between urbanized space, agricultural space, and the spaces of water and energy.

\subsection{Energy Production and Distribution}

Energy, like water, modifies and uses space. For the same reasons it requires a project that can strongly affect territorial planning. "Oil pipelines, dams, solar panels, nuclear plants or wind farms, all industrial energy systems deploy space, capital and technologies to construct their geographies of power and inscribe their technological order as a mode of organizing social, economic and political relations"(Ghosn $2010,7)$. The energy project, like that of water, requires a reflection on the alternative hypothesis of spatial organization of the networks that have deep effects on the way one conceives the territory. The current electrical energy distribution networks, for example, use transmission technology by now considered obsolete (Battaglini et al. 2008). They are fundamentally based on a tree structure and are strongly hierarchical: electrical energy production is concentrated in a few big stations (thermoelectric or hydroelectric), and the transport of the generated electricity is accomplished by way of huge transmission networks with the final distribution entrusted to lesser, capillary networks. According to the National Italian Agency for New Technologies and Sustainable Development (ENEA 2010), this model entails considerable losses during transmission, affecting the final cost of the available energy.

This model of functioning today no longer seems to be capable (neither from the point of view of its efficiency, nor in terms of safety) of contemplating new models of energy generation, transmission, distribution, and accumulation. In the light of climate change and diffuse systems for producing renewable energy, new models feature dispersion, interconnection, and flexibility of production in time and throughout the territory.

This is why, according to ENEA, the best solution for Italy would be the rapid transformation of the current system into a Distributed Generation (DG) electrical energy network model. ${ }^{v}$ The Distributed Generation model is based on many small-scale electrical generation systems that are modular and geographically close to the end consumer, with the 
possibility of being supplied by renewable energy sources (usually under a cogenerative structure). With the network moving to a system of Distributed Generation the operation of the network will change radically, going from the current "passive" operational model to an "active" and "intelligent" system (smart grid) (ENEA 2010, 63).

Beyond the importance of the next generation networks, their potential benefits, and the possible problems to their expansion (U.S. DOE 2007), what should be highlighted in this context are the implications that a change of paradigm of this extent might have for urban planning and design, also in the light of the deep and proven relations existing between the current network configuration and territorial organization (Donadoni 2012). It has been observed how the modern and rationally organized European cities, and the spaces and the parts that make them up, are also the result of a hierarchical organization of its networks (be these water, electrical, or mobility networks) (Secchi 2005). Starting from the topological organization of the infrastructure, in particular of the mobility infrastructure, the articulation and hierarchy found its greatest expression during the nineteenth century in the urban space of the European city. High-capacity mobility networks and electrical networks for high-voltage transmission have contributed to giving form and substance to a specialized and sectorialized territory. The consolidation of a paradigm of energy that favors dispersion to concentration of production, and isotropy to the hierarchy of the networks, will have inevitable and profound effects on how the territory is understood and planned.

\subsection{Diffuse Energy}

The expression "diffuse energy" is used to illustrate the potentialities of strategies aimed at the production of distributed electrical energy through the multiplication of potential energy operators and the spread of small systems throughout the territory. This model of energy production is opposed to the traditional Italian one that is based on a few large hydroelectric plants concentrated in a few locations. The expression is also used to indicate that the diffuse production of energy would cohere with the organizational principles of the città diffusa and the hierarchically weak urban conditions featured in territorial dispersion.

The Veneto region is an exemplary case of settlement dispersion and the capillary distribution of a minute network of waterways and roadways, a territorial distribution pattern that is prevalently isotropic. To describe this organization of the water and mobility networks we have proposed the adoption of the term "sponge." The sponge in our study on mobility is the dense web of roads and waterways that innervates the territory of the "diffuse city" of the Veneto that constitutes the main substrate for phenomena of settlement dispersion (Fabian 2012).

This condition of urban dispersion corresponds to high energy consumption ${ }^{\text {vi }}$ and an energy model that features the concentration of production in a few medium- or largescale thermoelectric and hydroelectrical plants. In 2009, 145 thermoelectric plants operated in the Veneto region and accounted for the production of about 70 percent of the total net output of electrical energy in the region (Terna 2009). This energy is almost entirely (94 percent) produced by seven large stations owned by two companies (ENEL and EDISON). Six of these power stations are concentrated in a small territory situated in the central area of the Veneto, located between the industrial area of Marghera, the Venice lagoon, and the Po River delta, in the province of Rovigo (Figure 5).

Comparing the gross production of energy with the consumption for 2002, the Regional Energy Plan for the Veneto shows that the location of the production plants is incoherent with the distribution of the energy consumed. This reflects the limitations of and the problem caused by the difference that exists between the current dispersed settlement structure model and the traditional location of the big thermoelectric plants, concentrated in a few areas with a ready and abundant supply of cooling water (Department Policies for Small and Medium Enterprises 2004).

The Regional Energy Plan highlights how from a condition of substantial autonomy in electrical energy in 2000, in less than ten years (by 2009) the Veneto has become a region that has to import around 50 percent of its electrical energy from external sources. In addition to the continued increase in energy consumption, the loss of energy autonomy is mainly due to the fact that the Veneto has come to rely on the production of electricity from a few large thermoelectric plants run on fuel oil, power plants that today cannot function at their full capacity because they operate using obsolete and polluting technology.

At the same time the Veneto was also one of the Italian regions that, starting from the postwar period, had invested the most in the production of electrical energy from renewable sources, thanks to the creation of huge hydroelectric plants in the Dolomites. The Veneto can today boast an energy production from renewable sources at around 10 percent of the regional needs. For environmental and climate change reasons, the huge hydroelectric plants, like the great thermoelectric plants, are being forced to lower their maximum capacity for energy production. In the analysis of the period between 1998 and 2003 the Regional Energy Plan attributes 26.8 percent of the progressive lowering of electrical energy production to the hydroelectric plants of the Dolomites and 16.2 percent to the thermoelectrical plants (Department Policies for Small and Medium Enterprises 2004).

The efficiency of a huge hydroelectrical system is based on the potential energy that it is capable of accumulating in its own water catchment basin. The greater the amount of water in the basin, the greater the energy produced and the energy efficiency of the plant. With climate change, longer periods of drought, and the regimentation of the "minimum vital flow" of the rivers downstream, the large plants find it ever harder to maintain a sufficient amount of water upstream to run the plants at their maximum.

Although the current systems for energy production and distribution have shown their limits, regional policy still seems to prefer, for the management of water and energy, 


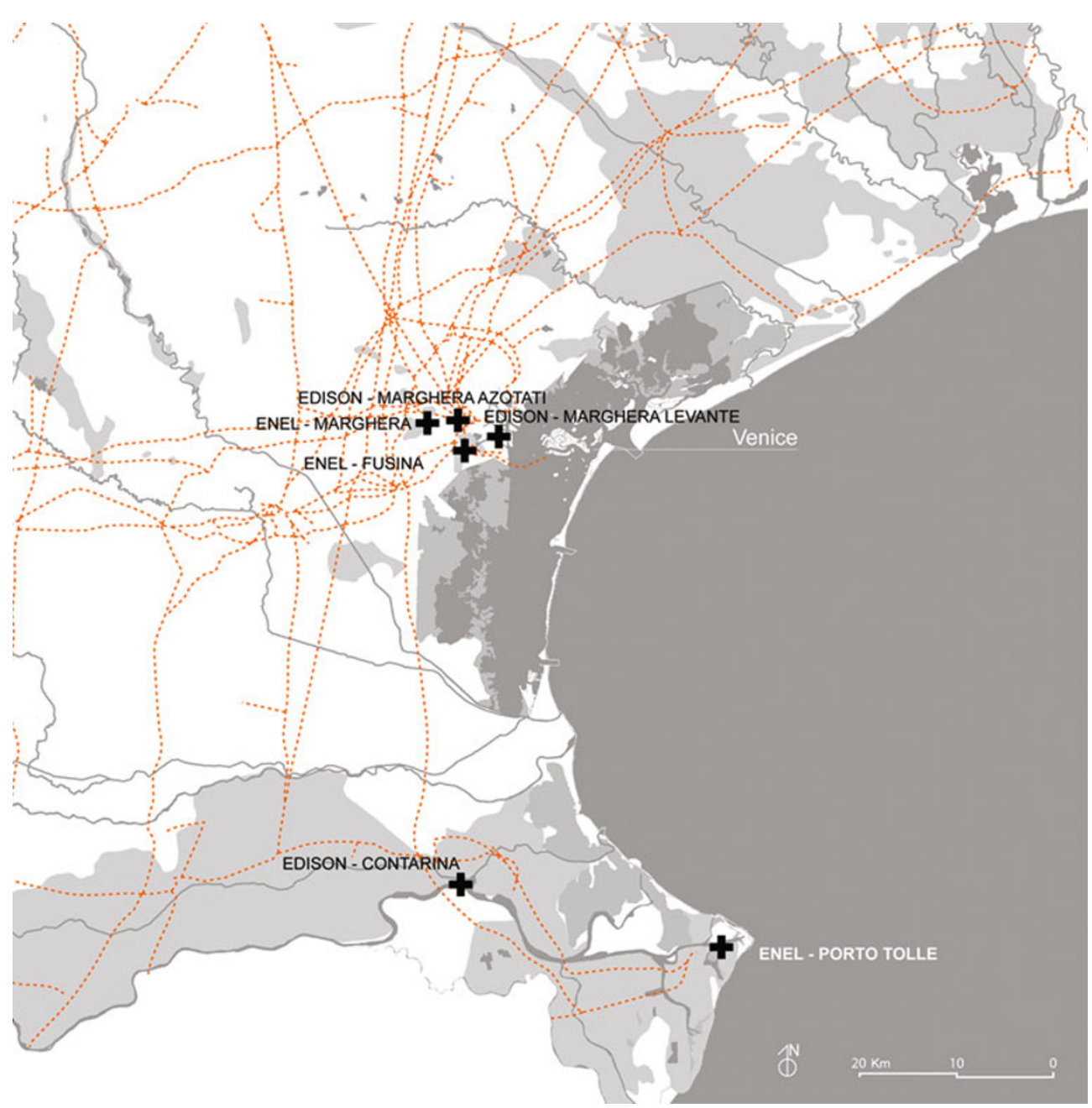

Figure 5. The main thermoelectric plants of the central Veneto area

Orange: power lines; black: main thermoelectric plants; light gray: floodplain.

Source of data: Regional Territorial Coordination Plan (Department of Land Policies, Veneto Region 2009); Water Protection Plan (ARPAV 2006).

models based on the principle of concentration of production and network hierarchization. Driven more by a desire for autonomy than the wish to contain emissions, the regional government signed an agreement with the Ministry for Economic Development in January 2011 for the conversion to coal of the largest Italian thermoelectric station at Porto Tolle in the Po delta. If this takes place, the station will be capable of guaranteeing 30 percent of the regional energy demand ( 5 percent of Italian demand).

The settlement dispersion and capillary water network that feature in the territories of the Veneto seem to suggest experimenting with alternative models for the creation of a strongly interconnected energy infrastructure, inspired by the paradigm of isotropy (Secchi and Viganò 2006; Fabian, Secchi, and Viganò 2012). According to this principle, the objective of energy saving and energy efficiency might be reached through the design of a new energy distribution network based on the principles of dispersion, flexibility, and the interaction of production and consumption of energy that reorganizes the redistribution of power throughout the territory (Rifkin 2002).
Given the effects they might have on territorial planning, some Italian experiences that are underway in the field of bottom-up organization and offer electrical energy production models based on the paradigm of isotropy and dispersion of production should be noted. The Eternit Free project carried out by Azzero $\mathrm{CO}_{2}$ - starting out from the new mechanism of financial incentivization in the field of renewable energy, the "energy account" (Ministry of Economic Development and Ministry for Environment and Protection of Natural Resources of the Italian Republic 2007) - entails the reclamation of asbestos roofing followed by the installation, on a vast scale, of photovoltaic systems on the roofs of agricultural and industrial buildings and warehouses. The project promotes the free reclamation of asbestos for buildings and warehouses of over $3500 \mathrm{~m}^{2}$ in size in exchange for the rights to manage the photovoltaic energy installed on the roofs for 20 years (Azzero $\mathrm{CO}_{2}$ 2011). Taking their example, thousands of citizens have chosen to benefit from the same incentivization laid down in the energy budget by choosing to invest in the restructuring of their own home while exploiting the energy potential produced as a source of income. Paradoxically, the 


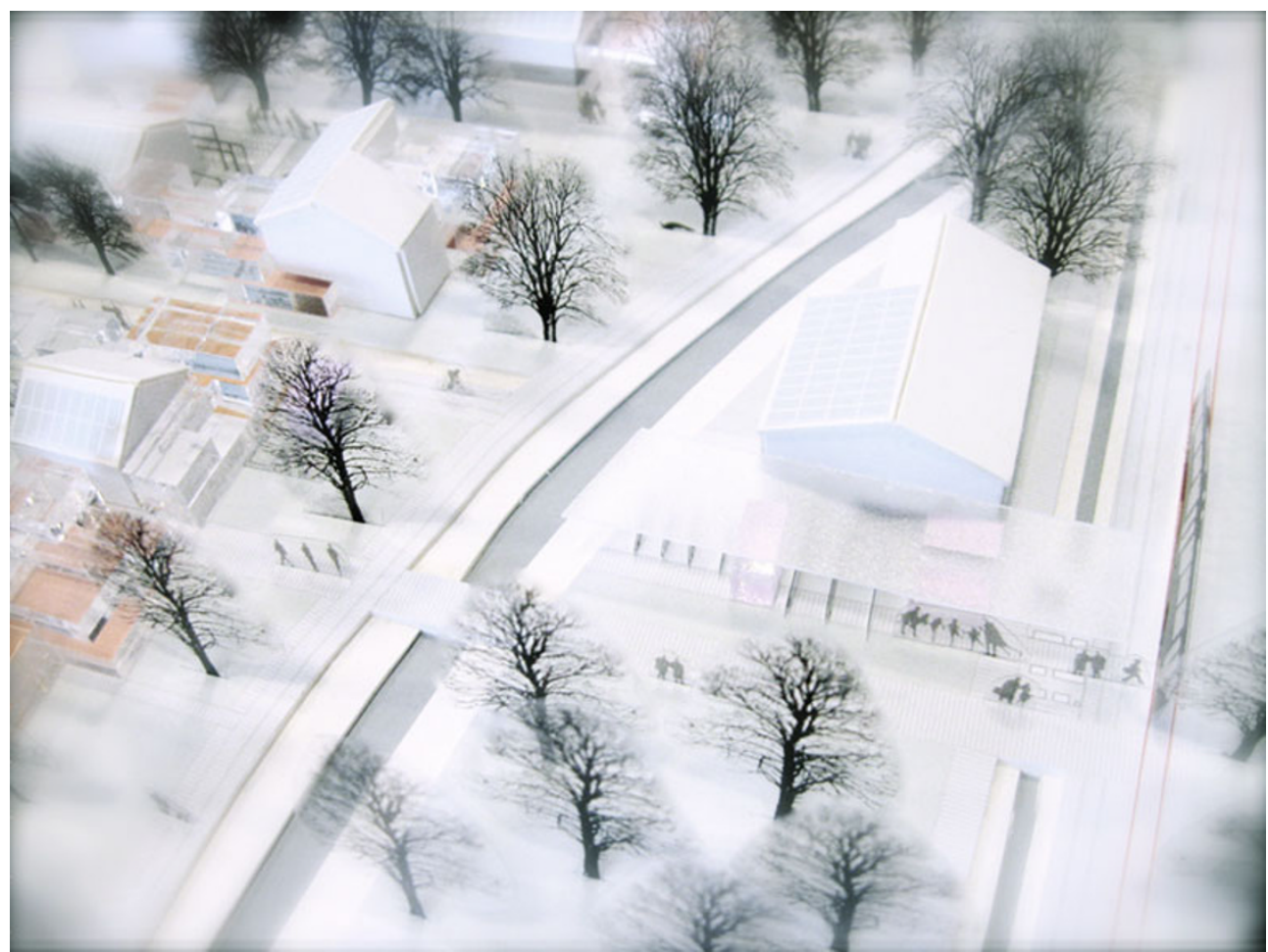

Figure 6. A diffused system of energy production in the renewed space of the città diffusa of the Veneto region Source: Causin 2011 (photo of model).

very dispersion of housing and the consequent extension of the roofing surfaces can be seen as a resource for the production of extensive amounts of renewable energy (Figure 6). At the same time, on the hydroelectric front, the potential of alternative energy models is seen to emerge as an alternative to the huge plants of the Dolomites. Recent experiences have shown how minute and capillary water networks can become an infrastructure capable of hosting a diffuse hydroelectric minisystem, exploiting the small changes in altitude, as occurred for years with mills.

The same principle of the spread of energy production could also be applied to the mobility network. A network of new woodlands along the rivers and roads could produce energy, absorb $\mathrm{CO}_{2}$, and configure a new and important ecological network spread throughout the territory following an isotropic pattern. The exploitation of the biomass collected with the mechanized cleaning and maintenance of the new woodlands could produce a considerable quantity of energy through systems of thermal and electrical energy cogeneration (Viganò 2010).

\section{Conclusion}

This article has attempted to illustrate, through the concept of the extreme city, the deep implications of the environmental and hydrogeological questions and their potential effect on the planning of the territory in the light of the climate change underway. A large part of the Italian territory is subject to hydrogeological risk and the extreme cities coincide increasingly with the ordinary territory. This is no small matter: apart from the potential risk to much of the ordinary territory the extreme city also reminds us that the problems of soil surface sealing and climate change can no longer be solved by extraordinary measures in the immediate aftermath of devastating effects. The project of the extreme city, the solutions to environmental risks and post-disaster urbanism in the Italian territory have to be the result of an ordinary process of continuous and progressive adjustment and maintenance of the territory and its infrastructural networks. The landscape of water and the landscape of energy can be the basis from which to start this progressive process of regeneration that begins from the territorial infrastructure of water and energy. Specialist fields such as environmental and energy engineering might help reshape a renewed territoryone less fragile from an environmental point of view, but also one that is more beautiful, featuring an improved quality of the environment and the landscape.

The "more space for water" concept illustrates how the water network can be redevised through the construction of large parks on a territorial scale to offer more space to water in case of flooding, but also to offer new spaces for biodiversity, new places for leisure time, sports, and sustainable mobility. If more space for water alludes to some possible project solutions of the top-down type, the "every drop counts" concept emphasizes the theme of water efficiency and the necessary application of bottom-up solutions that imply a different way of designing single housing cells, private garden spaces, and small plots of land. The "diffuse energy" concept introduces the theme of mitigating $\mathrm{CO}_{2}$ 
emissions and the possible spatial implications for the territorial project. It provides an introduction to the potential changes of scale within the territory in organizing the power networks, the settlements, and the mobility networks, as well as to the potential changes of scale of the single building units through the adaptation and restructuring of the existing housing stock. On a large scale, these projects and experiences represent the enormous potential of a broad and diffuse process of recycling of materials and infrastructure that make up the existing city (Viganò 2012).

The water and energy project can provide an opportunity for reconceptualizing the entire legacy of manmade and natural structures and items that constitute the territorial dispersion as well as providing a horizon of shared meaning to the entire complex of infrastructural and individual mobility projects. The ideal figure of isotropy can indicate a potential evolution for the territory starting from the specific features that make up the same. Houses, warehouses, huts, streams, rivers, drainage channels, roads, and ditches can be transformed, reconceived, and reinvented to take part collectively in the construction of a greater project starting from environmental and energy themes, that is capable of involving the entire diffuse city of the Veneto.

\section{Notes}

i With respect to climate change and the transformations in the water networks, see Fabian and Viganò 2010a and 2010b.

ii Ancient Roman field structuring system. The latin term refers to the layout of the colonization of territories in the Etruscan-Roman era.

iii This article sums up and reviews some of the recent teaching and research experiences made by the author at the University IUAV of Venice in the research group coordinated by B. Secchi and P. Viganò.

iv According to the Kyoto protocol by 2012 Europe is to have reduced its greenhouse gas emissions by $8 \%$ of figures registered in 1990 . The specific figure for Italy has been set at $6.5 \%$, or $12.6 \%$ of the value registered in 2000. By 2020 the EU "climate package" requires a $20 \%$ reduction of $\mathrm{CO}_{2}$ emissions (target year 1990), and a $20 \%$ increase of energy efficiency and renewable energy production that covers at least $20 \%$ of the entire EU needs. In line with this process, Roadmap 2050, a study promoted by the European Climate Foundation, has as its objective the analysis of the ways needed to reduce greenhouse gas emission by $80 \%$ by 2050 (target year 1990).

v Distributed Generation is the production of electrical energy from small units spread throughout the territory, a system that lends itself effectively to the networking of renewable energy generating plants. These production plants are generally connected to the low-voltage grid. See U.S. DOE 2007.

vi In Italy, the Veneto region, alongside Lombardy, Puglia, and Emilia Romagna, has the highest energy consumption as well as the highest emissions in absolute values. See Mancuso 2010.

\section{References}

ARPAV (Veneto Environmental Protection Agency). 2006. Water Protection Plan (Piano di Tutela delle Acque). Veneto Environmental Protection Agency.
Azzero $\mathrm{CO}_{2}$. 2011. Eternit Free. Remove the Asbestos from Your Territory and Replace It with Photovoltaics (Eternit Free. Elimina l'eternit dal tuo territorio e sostituiscilo con il fotovoltaico). http:// www.azzeroco2.com/eternitfree/default.asp?id=516.

Barbi, A., G. Formentini, M. Monai, F. Rech, and F. Zardini. 2007. Meteo-Climatic Analysis of the Pluviometric Event of 26 September 2007 in the Area of Venice (Analisi Meteo-Climatica Dell'Evento Pluviometrico del 26 Settembre 2007 nel Veneziano). ARPAV Regional Department for Territorial Safety, Teolo Meteorological Center.

Battaglini, A., J. Lilliestam, C. Bals, and A. Haas. 2008. The Super Smart Grid. European Climate Forum. Potsdam Institute for Climate Impact Research. http://www.germanwatch.org/klima/ssg08.pdf.

Bevilacqua, P. 1989. The Revolutions of Water. Irrigation and Transformation of Agriculture between the 18th and the 20th Century (Le rivoluzioni dell'acqua. Irrigazioni e trasformazioni dell'agricoltura tra Sette e Novecento). In History of Italian Agriculture in Contemporary Times (Storia dell'agricoltura italiana in età contemporanea), Vol. I, edited by P. Bevilacqua, 255-318. Venice: Marsilio.

Bevilacqua, P., and M. Rossi-Doria, eds. 1984. Land Reclamation in Italy from the 18th Century to This Day (Le bonifiche in Italia dal '700 a oggi). Rome: Laterza.

Bixio, V. 2009. Physical and Climatic Characteristics of the Reclaimed Districts of the Veneto (Caratteri fisici e climatici dei comprensori di bonifica del Veneto). Venice: Edizioni Regione Veneto-Giunta Regionale.

Causin, S. 2011. Diffuse Energy (Energia Diffusa). University degree thesis in Architecture. University IUAV of Venice.

Comerci, V., and P. Di Manna. 2010. Second Verbal Account of the Survey of the Maierato (VV) Landslide (Secondo Verbale di Sopralluogo sulla Frana di Maierato (VV)). ISPRA, Institute for Protection and Environmental Research, and DDS, Environmental Defense Department of the Italian Geological Service, Vibo Valentia.

Conte, M., R. Sorani, and E. Piervitali. 2002. Extreme Climatic Events over the Mediterranean. In Mediterranean Desertification: A Mosaic of Processes and Responses, edited by N. A. Geeson, C. J. Brandt, and J. B. Thornes, 15-31. Chichester: John Wiley.

De Geyter, X. 2002. After Sprawl. Research for the Contemporary City. Rotterdam: Nai Publishers.

Dematteis, G. 1995. Implicit Project. The Contribution of Human Geography to the Territorial Sciences (Progetto implicito. Il contributo della geografia umana alle scienze del territorio). Milano: Franco Angeli.

Department of Land Policies, Veneto Region. 2009. Regional Territorial Coordination Plan (PTCR, Piano Territoriale di Coordinamento Regionale). Veneto Region.

Department Policies for Small and Medium Enterprises. 2004. The Regional Energy Plan, Veneto Region (Piano Energetico Regionale). Assessorato PMI, Regione Veneto, Venice.

Donadoni, E. 2012. Representing Networks. An Atlas of Reticular Spaces (Rappresentare le reti. Un atlante ragionato di spazi reticolari). Ph.D. thesis in Urbanism. University IUAV of Venice.

ECF (European Climate Foundation). 2010. Roadmap 2050: A Practical Guide to a Prosperous, Low-Carbon Europe. European Climate Foundation. http://www.roadmap2050.eu/.

EEA (European Environment Agency). 2004. DTM 2004 (Digital Terrain Model Database). European Environment Agency.

. 2007. Corine Land Cover 2000 Seamless Vector Database (Version 9/2007). European Environment Agency.

ENEA (National Italian Agency for New Technologies and Sustainable Development). 2010. Energy and Environmental Report, Analysis and Scenarios 2009 (Rapporto Energia e Ambiente, Analisi e Scenari 2009). Rome: ENEA.

ERSAF (Regional Agricultural and Forestry Service, Regione Lombardia). 2010. Land Use in the Lombardy Region, Dusaf Territorial Database Figures (Uso del suolo in Regione Lombardia, i dati Dusaf, edizione). Regione Lombardia in cooperation with the Regional Body for Agricultural and Forestry Services, Milan. 
EU (European Union). 2000. Directive 2000/60/EC of the European Parliament and of the Council of 23 October 2000 Establishing a Framework for Community Action in the Field of Water Policy. http:// eur-lex.europa.eu/LexUriServ/LexUriServ.do?uri=CELEX:32000 L0060:EN:NOT.

Fabian, L. 2012. Pipes and Sponges 2: Maps and Models for the Mobility Network (Tubi e spugne 2: mappe e modelli per la rete della mobilità). In On Mobility 2, Reconceptualizing Mobility in Diffuse City (On Mobility 2, Riconcettualizzazioni della mobilità nella città diffusa), edited by L. Fabian and P. Pellegrini, 49-64. Venice: Marsilio.

Fabian, L., B. Secchi, and P. Viganò. 2012. The Project of Isotropy. An Exhibition, a Research Study, a Project (Il progetto dell'isotropia. Una mostra, una ricerca un progetto). Exhibition at University IUAV of Venice. http://www.extremecities.net/isotropia.

Fabian, L., and P. Viganò, eds. 2010a. Extreme City. Climate Change and the Transformation of the Waterscape. Venice: IUAV Press.

2010b. The Extreme City. Climate Change and the Transformation of the Waterscape. In Territorio 52 (10): 91-101.

Ghosn, R. 2010. Energy as a Spatial Project. In Landscapes of Energy, New Geographies 02, edited by R. Ghosn, 7-11. Cambridge: Harvard University Press.

Gissi, E. 2010. From Risk to Resources: Water Management for the Project of the Landscapes of Dispersion on the Plain of Southern Veneto, in the Climate Change Scenario (Da rischio a risorsa: la gestione delle acque per il progetto dei paesaggi della dispersione della pianura del basso Veneto, nello scenario dei cambiamenti climatic). Full paper at Climate, Growth and Cohabitation, 13th Congress of the Italian Urbanism Association (Clima, Sviluppo E Convivenza Siu XIII Conference), 25-27 February 2010, Rome.

Holling, C. S. 1973. Resilience and Stability of Ecological Systems. Annual Review of Ecology and Systematics No. 4: 1-23.

Hulsker, W., M. Wienhoven, M. Diest, and S. Buijs. 2011. Evaluation of Design Processes, Space for the River (Evaluatie ontwer processen. Ruimte voor de Rivier). Rotterdam: ECORYS Nederland BV.

Indovina, F., ed. 1990. The Diffuse City (La città diffusa). Venice: Department of Social and Economic Analysis of Land (Dipartimento di Analisi Economica e Sociale del Territorio), IUAV (Istituto Universitario di Architettura di Venezia).

IPCC (Intergovernmental Panel on Climate Change). 2007. Mitigation. Contribution of Working Group III to the Fourth Assessment Report of the Intergovernmental Panel on Climate Change, edited by B. Metz, O. R. Davidson, P. R. Bosch, R. Dave, and L. A. Meyer. Cambridge: Cambridge University Press.

Legambiente, Civil Defense Department. 2010. Ecosystem Risk 2010: Monitoring of the Activities of the Communal Administrations for the Mitigation of Hydrogeological Risks (Ecosystema rischio 2010: Monitoraggio sulle attività delle amministrazioni comunali per la mitigazione del rischio idrogeologico). Civil Defense Department of Italy. http://www.legambiente.it/sites/default/files/docs/ecosistema rischio 2010 dossier.pdf.

Mancuso, E. 2010. Annual Inventory for Italy of Greenhouse Gas Emissions on a Regional Scale (Inventario Annuale delle Emissioni di Gas Serra su Scala Regionale). Rome: ENEA (National Italian Agency for New Technologies and Sustainable Development).

McNeill, J. R. 2000. Something New Under the Sun: An Environmental History of the 20th Century World. New York: Norton.

Ministry of Culture and Communication of the French Republic. 2009. The Greater Paris (Le Grand Paris ). International consultation promoted by the Ministry for Culture and Communication of French Republic. http://www.legrandparis.net/.

Ministry of Economic Development and Ministry for Environment and Protection of Natural Resources of Italian Republic. 2007. DECREE 19 February 2007, Criteria and Modalities to Promote the Generation of Electricity by the Photovoltaic Conversion of Solar Energy
(DECRETO 19 febbraio 2007, Criteri e modalità per incentivare la produzione di energia elettrica mediante conversione fotovoltaica della fonte solare). Parliament of Italian Republic, Rome.

Munarin, S., and M. C. Tosi. 2000. Traces of City (Tracce di città). Milano: Angeli.

NBEPA (Netherlands Bureau for Economic Policy Analysis). 2005. Explanatory Memorandum, PKB Part 4. Rotterdam: NBEPA.

OMA (Office for Metropolitan Architecture). 2010. Graphic Narrative of Roadmap 2050: A Practical Guide to a Prosperous, Low-Carbon Europe, Vol. 3. OMA, European Climate Foundation. http://www. roadmap2050.eu/attachments/files/Volume3_FullBook.pdf.

ONCS (National Observatory of Land Use). 2009. First Report 2009 (Primo Rapporto 2009). National Observatory of Land Use. Milan: Maggioli Editore.

Perec, G. 1996. The Infra-Ordinary (L'Infra-ordinaire). Paris: Edition du Seuil.

Pesavento, S. M. 1998. Reclamation and Drainage with Amphoras in the Roman Era: Technical and Topographic Aspects (Bonifica e Drenaggi con Anfore in Epoca Romana: Aspetti Tecnici e Topografici). Modena: F. C. Panini.

Petrella, R. 2002. Antonio's Well. Water in Italy, or Emergency as a Policy (Il pozzo di Antonio. L'acqua in Italia, o l'emergenza come politica). Torino: Edizioni Gruppo Abele.

Pileri, P. 2010. Land Use and the Release of Carbon into the Atmosphere. Planning Can Help (Consumo di suolo e rilascio di carbonio in atmosfera. Il piano può fare qualcosa). Full paper at Climate, Growth and Cohabitation, 13th Congress of the Italian Urbanism Association (Clima, Sviluppo E Convivenza Siu XIII Conference), 25-27 February 2010, Rome.

Rifkin, J. 2002. The Hydrogen Economy. New York: Penguin Group.

Schuetze, T., and S. P. Tjallingii, eds. 2008. Every Drop Counts. Environmentally Sound Technologies for Urban and Domestic Water Use Efficiency. Delft/Osaka: TUDelft/UNEP.

Secchi, B. 1986. Land Use Project (Progetto di suolo). Casabella No. 520: $19-24$.

2005. The Cities of the 20th Century (La città del XX secolo). Bari: Laterza.

Secchi, B., and P. Viganò. 2006. The Project of Isotropy (Il progetto dell'isotropia). Venice Biennale, 20th International Architecture Exhibition, Venice, 2006.

Structure of the Extraordinary Commission for Recovering from the Flooding. 2011. Veneto. The Great Flood (Veneto. La grande alluvione). Veneto Region, Venice.

Terna (National Electricity Transmission Grid). 2009. Electricity in the Italian Regions (L'elettricità nelle regioni). Rome: Terna Spa.

U.S. DOE (U.S. Department of Energy). 2007. The Potential Benefits of Distributed Generation and Rate-Related Issues that May Impede Their Expansion. http://www.ferc.gov/legal/fed-sta/exp-study.pdf.

Viganò, P., U. degli Uberti, T. Lombardo, G. Lambrecht, and G. Zaccariotto. 2009. Landscapes of Water (Paesaggi dell'acqua). Pordenone: Risma.

2010. Planning Mobility in a Diffuse City (Il progetto della mobilità in una città diffusa). In On Mobility. Infrastructure for Mobility and Construction of the Metropolitan Territory: Guidelines for an Integrated Project (On Mobility. Infrastrutture per la mobilità e costruzione del territorio metropolitano: linee guida per un progetto integrato), edited by B. Secchi, 29-40. Venice: Marsilio.

. 2012. Recycle City (Riciclare città). In Re-cycle, edited by P. Ciorra and S. Marini, 102-19. Milan: Electa.

Zaccariotto, G. 2010. Integrated Urban Landscape: Water Sensitive Design for the Diffuse City of the Veneto Region. Ph.D. thesis in Urbanism. University IUAV of Venice.

Zanchini, E. 2010. Another Home? (Un'altra casa?). Legambiente. http://www.legambiente.it/sites/default/files/docs/dossier_unaltracasa. pdf.

Open Access This article is distributed under the terms of the Creative Commons Attribution License which permits any use, distribution, and reproduction in any medium, provided the original author(s) and source are credited. 